Florida International University FIU Digital Commons

FIU Electronic Theses and Dissertations

University Graduate School

3-20-2010

\title{
Exploring Armenian keyboard music : roots to modern times
}

Marina Berberian

Florida International University

DOI: $10.25148 /$ etd.FI14051105

Follow this and additional works at: https://digitalcommons.fiu.edu/etd

Part of the Music Commons

\section{Recommended Citation}

Berberian, Marina, "Exploring Armenian keyboard music : roots to modern times" (2010). FIU Electronic Theses and Dissertations. 1604.

https://digitalcommons.fiu.edu/etd/1604

This work is brought to you for free and open access by the University Graduate School at FIU Digital Commons. It has been accepted for inclusion in FIU Electronic Theses and Dissertations by an authorized administrator of FIU Digital Commons. For more information, please contact dcc@fiu.edu. 


\section{FLORIDA INTERNATIONAL UNIVERSITY}

Miami, Florida

EXPLORING ARMENIAN KEYBOARD MUSIC: ROOTS TO MODERN TIMES

A thesis submitted in partial fulfillment of the

requirements for the degree of

MASTER OF MUSIC

by

Marina Berberian

2010 
To:Acting Dean Brian Schriner

College of Architecture and the Arts

This thesis, written by Marina Berberian, and entitled Exploring Armenian Keyboard Music: Roots to Modern Times, having been approved in respect to style and intellectual content, is referred to you for judgment.

We have read this thesis and recommend that it be approved.

Joel Galand

Jose Lopez

Kemal Gekic, Major Professor

Date of Defense: March 20, 2010

The thesis of Marina Berberian is approved.

Acting Dean Brian Schriner

College of Architecture and the Arts

Interim Dean Kevin O'Shea

University Graduate School

Florida International University, 2010 


\section{DEDICATION}

For their loving support, this thesis is dedicated to:

Manuel Berberian,

Phil Berberian,

And to my children Olga, Kerop, and Emmanuelle 


\section{ABSTRACT OF THE THESIS \\ EXPLORING ARMENIAN KEYBOARD MUSIC: ROOTS TO MODERN TIMES}

by

Marina Berberian

Florida International University, 2010

Miami, Florida

Professor Kemal Gekic, Major Professor

The extended program notes include historical facts of the composers and characteristics of the pieces being performed. The thesis also includes information about Armenian composers starting from $18^{\text {th }}$ to the $20^{\text {th }}$ century, composition's historical background, brief biographies of the composers as well as analysis of form and structure. The graduate piano recital comprised the following compositions: Sayat Nova-R. Andriasian Yes Mi Kharib Blbuli Pes; Komitas - R. Andriasian Garun a, Shoker Jan, Dzirani Dzar, Gakavik; A.Khachaturyan Poem; A. Babadjanyan Elegy in Commemoration of A. Khachaturyan; E. Bagdasarian Humoresque, Prelude in D Minor, Prelude in B Minor; A. Babadjanyan Improvisation and Traditional from six Pictures; A. Babadjanyan Prelude and Vagarshapat Dance; A. Arutyunian Dance of Sasoon; A. Arutyunian - A. Babadjanyan Armenian Rhapsody for Two Pianos. 


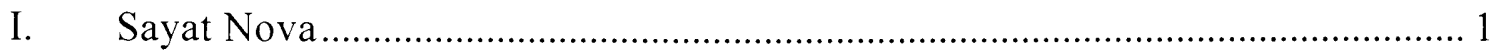

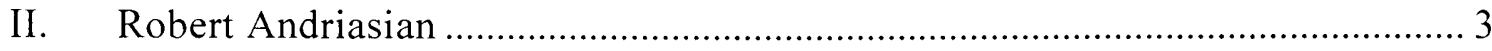

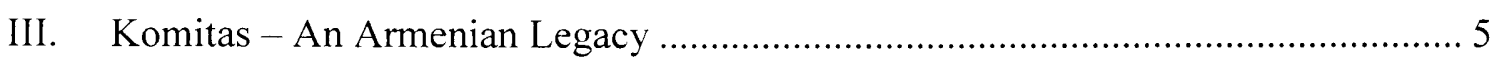

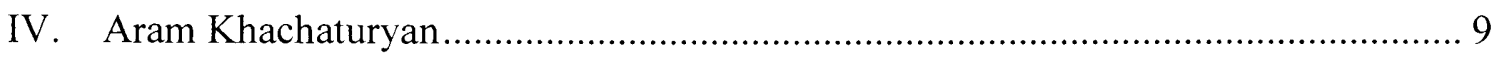

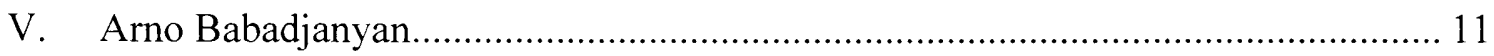

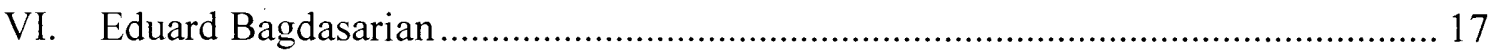

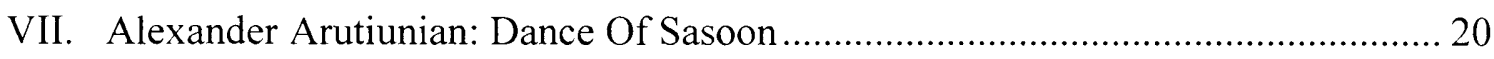

VIII. A. Arutiunian - A. Babadjanyan: Armenian Rhapsody For Two Pianos ............... 22

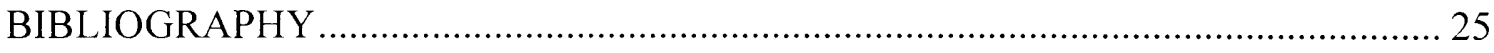




\section{LIST OF FIGURES}

FIGURE

1. Andriasian: Yes Mi Kharib Blbuli Pes, opening. ….................................................... 4

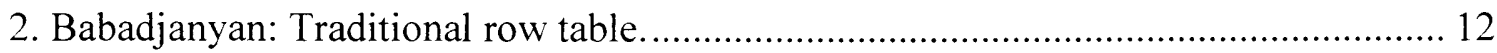

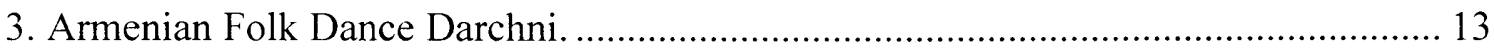

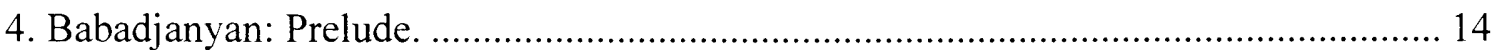

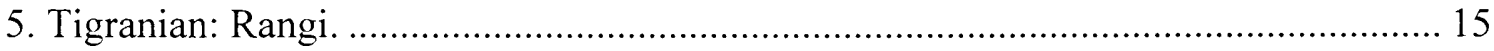

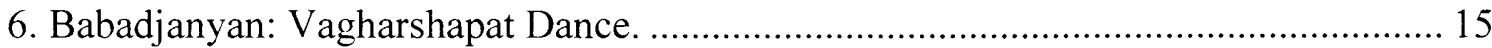

7. Bagdasarian: Prelude, opening theme

8. Bagdasarian: Prelude, A section overview. .............................................................. 18

9. Bagdasarian: Prelude, an overview of the form........................................................ 19

10. Arutiunian-Babadjanyan: Armenian Rhapsody for Two Pianos............................... 23

11. Arutiunian-Babadjanyan: beginning of the Allegro section. .................................. 24 


\section{CHAPTER I}

\section{SAYAT NOVA}

Sayat Nova, which means "King of Songs," is the name given to the great Armenian troubadour Harutyun Sayatyan (June 14, 1712 - September 22, 1795), who excelled equally as poet, singer-songwriter and diplomat. He was born to a peasant family in the village of Sanahin, not far from Tiflis, the capital of the Caucasian nation of Georgia.

As a boy, Harutyun gained regional recognition for his fine singing voice, his interpretations of folk songs, and his emerging virtuosity on the kemenche - a coneshaped body string instrument with three strings tuned in fourths - and played with a bow, using the German-style bowing often employed by bass players. The normal playing position for the kemenche is on the left knee, using the left hand for fingering and the right for bowing. He also accompanied himself on the ch'onguri or Georgian lute, and the t'ambur, most likely the Caucasian t'ar. The young man was also recognized as the author of beautiful lyric poetry. When his family moved to Tiflis, Sayat Nova was employed as an apprentice to a weaver, an experience that he reflected later in his songs.

By the age of eighteen, Sayat Nova was already performing as a minstrel, and by age thirty he was renowned for his proficiency on various instruments. This would eventually enable him to perform in the court of Heraclius II of Georgia, where he also worked as a diplomat, becoming the King's trusted advisor and helping to forge an alliance between Georgia, Armenia and Shirvan against the Persian Empire. His fluency in Georgian, Persian, Arabic, Armenian and Azerbaijani allowed him to perform for the widest possible audience, and to gain fame far beyond his own ethnic group. His fall from grace 
in the Court is likely to have been caused by his love for the King's sister, Princess Anna. The King, fearing the power and influence that would likely accrue to Sayat Nova as a result of a marriage to Anna, expelled the great minstrel from the Court.

The known body of songs attributed to Sayat Nova numbers about 220, although the actual volume of work is likely to have been in the thousands. His chief themes were social ones, notably the liberation of his people. The subject of love was also basic, sometimes expressed with touching directness or in striking imagery, always hyperbolic. In addition, he gave prominence to social, philosophical, and ethical themes, celebrating human virtues and censuring negative aspects of social and individual existence. It should be noted that these works, though notated in the nineteenth century, have been largely passed down as an oral tradition. His major songs are not happy ones. But enough of his life is known for us to realize that their complaints derive from defiance in the face of genuine suffering. ${ }^{1}$

It is a fact, that to this day, it would be difficult to find an Armenian who did not know a song by Sayat Nova, since his songs are widely known in any Armenian community and are an important part of every Armenian folk musician. Me khosk unim "I have a word to say." So have we all, and he says it for us.

\footnotetext{
${ }^{1}$ Charles Dowsett, Sayat'-nova: An 18th-century Troubadour: a Biographical and Literary Study (Lovanii In Aedibus Peeters, 1997), 3.
} 


\section{CHAPTER II}

\section{ROBERT ANDRIASIAN}

In addition to being an excellent pianist and accomplished composer, Robert Andriasian (1913-1971) was a skillful editor and an exceptional music transcriber and arranger. He was educated at the Leningrad State Conservatory and was praised at a young age by Dimitri Shostakovich for the high quality of his performances.

Among his many valuable arrangements for the piano are the following folk songs collected and published by the great Komitas (see chapter three): Garun a, Gakavik, Dzirani Dzar, and Shokher jan. These are among the most well known folk songs among Armenians all over the world. Andriasian's arrangements became models for concert renditions of Armenian piano literature. Khachaturyan noted that those arrangements are done by the "hand of an expert." They retain the structure of Komitas' collection of folk songs, even though the European and Russian pianistic traditions are pronounced as well.

One of Andriasian's great accomplishments, however, was his arrangement for piano of the famous $18^{\text {th }}$ century troubadour, Sayat Nova's, songs. In his arrangements, he sought to capture the spirit and the essence of the compositions, while keeping the features of the original songs. In Figure 1, the opening arpeggiated chords of Yes Mi Kharib Blbuli Pes are Andriasian's attempt to mimic the kemenche - the original instrument this piece was interpreted on, and one of the most important instruments played by the great Sayat Nova.

\footnotetext{
${ }^{2}$ Shooshanik Apoian, Robert Andriasian (Yerevan: Sovetakan Grox, 1984), 58.
} 


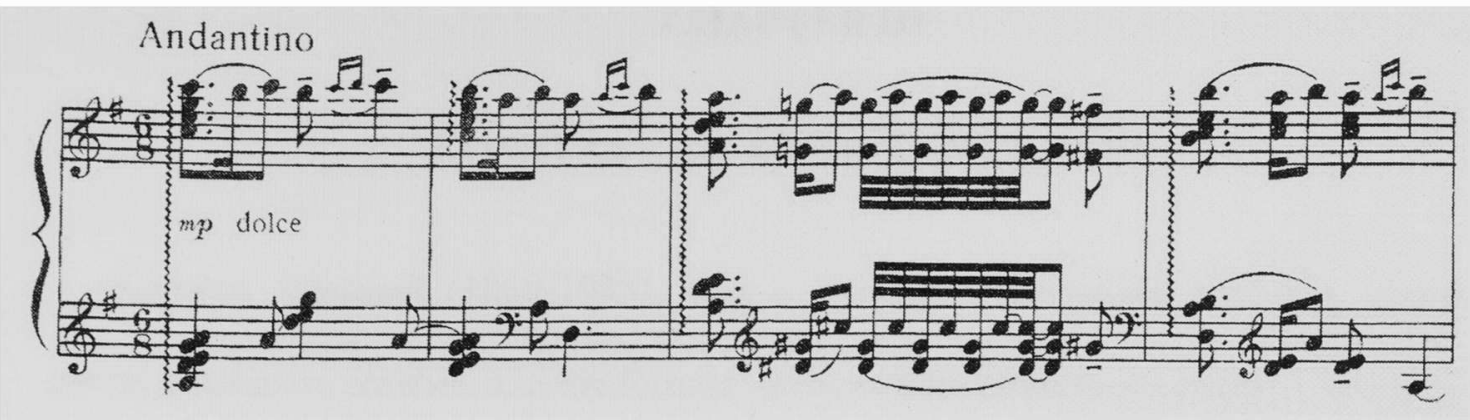

Figure 1. Andriasian: Yes Mi Kharib Blbuli Pes, opening. 


\section{CHAPTER III}

\section{KOMITAS - AN ARMENIAN LEGACY}

Komitas Vardapet (1869-1935), was a renowned Armenian musician, composer, choral conductor, teacher, and the founder of Armenian ethnomusicology.

Komitas, born Soghomon Soghomonyan, was born in Asia Minor into a family whose members had a fond appreciation for music. Both his parents - his father a shoemaker and his mother a carpet weaver - had a strong love for music and sang frequently in their everyday lives. ${ }^{3}$

Orphaned at a young age he was educated at the Echmiadzin Seminary and became a monk. According to Armenian church tradition, newly ordained priests are given a new name, and Soghomon was renamed Komitas (named after a seventh century Armenian Catholicos who was also a hymn writer). At the seminary, Soghomon's talent as a very young singer brought him to the attention of Bishop Catholicos Gevork IV, who had proposed that the youth of Armenia "should be nurtured and encouraged in their artistic abilities. $^{.4}$

He continued his education in Berlin at Kaiser Friedrich Wilhelm University. After returning to Armenia, Komitas traveled extensively around the country, listening to and recording details about Armenian folk songs and dances in various villages. In September 1899, at the age of 30 , Komitas returned to the Etchmiadzin Monastery, where he put his

\footnotetext{
${ }^{3}$ Virtual Museum of Komitas, "Biography of Komitas," Virtual Museum of Komitas, http://www.komitas.am/ eng/brief.htm (accessed August 30, 2008).

${ }^{4}$ Archbishop Torkom Manoogian, The Genius of Gomidas (Gomidas Vartabed, His Life and Work on the Centennial of His Birth, trans. Shahan R. Berberian (New York: Diocese of the Armenian Church of America, 1969), 27.
} 
musical talents and training to immediate use. Within months, Komitas radically changed the way music was taught at the seminary, founded an orchestra, and raised the performance level of the Etchmiadzin choir.

In 1910, Komitas left Etchmiadzin and went to Constantinople. His goals were to establish a National Conservatory, where he could guide the destiny of his people's music. He created a historical choir consisting of about 300 men and named it "Goosing", meaning "longing". The choir became very popular; their repertoire comprised mostly of Armenian folk songs. Touring as a soloist and conductor, and lecturing became a part of his everyday life. He was a master flutist and pianist and possessed a rich and expressive baritone voice. ${ }^{5}$ Composers such as Vincent D'Andy, Camille Saint-Saens, and Gabriel Faure admired Komitas' creative work. A special encomium came in 1906 from Claude Debussy, who after one of Komitas' concerts in Paris, excitedly exclaimed: "Brilliant father Komitas! I bow before your musical genius!"

His compositional activity placed special emphasis on church music; Patarag ("Liturgy") for male chorus is one of his masterpieces. He also traveled to Paris and presented two lectures at the Conference of the International Music Society: "Armenian Folk Music" and "On Old and New Notation of Armenian Spiritual Music". Komitas captured the interest of many of the attendees at the conference and was requested to give an additional presentation on the topic: "On Time, Place, Accentuation and Rhythm of Armenian Music."

\footnotetext{
${ }_{5}^{5}$ Rita Soulahian Kuyumjian, Archeology of Madness: Komitas, Portrait of an Armenian Icon (Reading, England: Taderon Press, 2001), 197.

${ }^{6}$ Sirvart Poladian, Armenian Folk Songs (Berkeley, CA: University of California Press, 1942), 97.
} 
During World War I, the government of Young Turks initiated their horrendous program of violent extermination of the Armenian race. In April 1915, Komitas was arrested, together with a number of outstanding Armenian writers, publicists, physicians, and lawyers. He became a witness to the brutal genocide of Armenian intelligentsia.

After the 1915 massacres of the Armenian people, he succumbed to mental and physical anguish and never fully recovered. He died in Paris in 1935 in a mental hospital. In the spring of 1936, his remains were transferred to the Pantheon of Armenian Artists in Yerevan, Armenia. Komitas Vardabed is considered one of the immortals of the Armenian Church and is remembered in the minds and hearts of all Armenians.

Komitas' musical output is voluminous and diverse, encompassing liturgical chants, art, and folk songs, and choral settings, all of which mirror, as no other composer's work has done, the Armenian ethos. He traveled extensively through the remotest regions of Armenia, listening to and notating Armenian folk songs and dances as performed by the villagers, thus saving them from virtual extinction. He collected close to three thousand such songs and melodies, not only in Armenian but also in Arabic, Kurdish, and Persian. His thorough assimilation of folk influence explains why the songs of Komitas resonate powerfully in Armenian consciousness.

Each of Komitas's three songs, transcribed for piano by R. Andriasian has its own atmosphere - a tragic Garun a ("Its Spring"), a humorous Gakavik ("Nightingale"), a somber, dramatic Dzirani Dzar ("Apricot Tree") - nevertheless, all possess an uncompromising, genuine, reserved expression, without extreme visceral outbursts. 
The human voice in song is the path which Komitas' compositional thinking takes. In his Divine Liturgy, the voices of the male chorus are woven into a layered, polyphonic composition. Similarly, in many of his art songs, the piano is treated as a singing instrument. 


\section{CHAPTER IV}

\section{ARAM KHACHATURYAN}

The remarkable music of Aram Khachaturyan (1903-1978) has been a concert hall staple internationally for some sixty years. It captivates the listener with its original colour palette and melodic inventiveness; having once entered the world of Khachaturyan's music, one cannot part with it.

Famous for his "Sabre Dance" from the ballet Gayane, Khachaturyan created music distinguished by improvisatory-sounding melodies, surging rhythms, acutely expressive harmonies, and colourful use of the orchestra. Most piano students are familiar with his brilliant "Toccata", and many virtuoso artists perform his Piano Concerto on a regular basis.

Khachaturyan's earliest musical impressions came from hearing folk music in Tbilisi, where he was born, and from his mother, who liked to sing Armenian folk songs. The composer recalled: "I grew up in an atmosphere of extraordinary rich folk music which permeated the people's life, its joys and sorrows, its holidays and ceremonies.",

In 1921, when he travelled to Moscow, Khachaturyan showed such a great talent that he was admitted to Gnessin Music Institute without any previous musical education. There, he studied cello and composition. By the time he graduated from the Moscow Conservatory in 1934, he was already known as a composer, the author of piano and violin pieces, songs and arrangements of folk melodies, and incidental music for dramas.

\footnotetext{
${ }^{7}$ G.M. Shneyerson, Aram Khachaturyan: Stranitsi Ghizni I Tvorchestva [Pages from His Life and Works] (Moskva: Sovetski Kompozitor, 1982), 35.
} 
The composer's contribution to orchestral music, and particularly to the concerto, symphonic, and ballet genres, is immense. "Poem" is the composer's earliest attempt to write music for piano. It was composed in 1926 and was heavily influenced by Armenian folk music. His use of many folk sources, especially of the ashugh (bard) tradition, accounts in part for his rhythmic diversity. Khachaturyan stated that his harmonic language came from "imagining the sounds of folk instruments with their characteristic tuning and resulting range of overtones," which explains his widespread harmonic use of seconds, fourths and fifths. ${ }^{8}$

Khachaturyan's music was on of the bridges that most effectively connected European and Eastern traditions during the twentieth century.

\footnotetext{
${ }^{8}$ Svetlana Sarkisyan, "Khachaturian, Aram (Il'ich)," Oxford Music Online, http://www.oxfordmusiconline.com.ezproxy.fiu.edu/subscriber/article/grove/music/14956?q=khachaturian \&search=quick\&pos=1\&_start=1\#firsthit (accessed November 28, 2008).
} 


\section{CHAPTER V}

\section{ARNO BABADJANYAN}

Armenian folk music has always figured largely in the music of Armenian composers. American-born Alan Hovhannes (1911-2000), Soviet composer Aram Khachaturyan (1903-1978), and Arno Babadjanyan (1921-1983), to name a few, were all strongly influenced by the tonal aura and folk-like element that define Armenian music. One of the most illustrious and extraordinary Armenian Soviet-era composers was Arno Babadjanyan. A brilliant pianist, Babadjanyan was "discovered" by Khachaturyan, entered Pr. Igumnov's piano class at the Moscow Conservatory, graduated in 1948, and became a highly-regarded musical personage in the former Soviet Union, where he was a close colleague of both Rostropovich and Shostakovich.

Everything created by Babadjanyan has its roots in the depths of the ancient Armenian folk music and folklore. His music draws on Khachaturyan and Rachmaninoff, but is unmistakably individual. The piano works are in a virtuoso style, liberal in their use of touch, texture, rhythm and register. This style was formed in 1940s; later he introduced Prokofiev-like chromaticism, Bartokian rhythm, and Schoenbergian dodecaphony into his music. ${ }^{9}$ His Six Pictures, one of his last compositions, written in 1965 , exemplifies these later developments.

The first piece from Six Pictures, "Improvisation" is composed in a recitative-like, quasi-improvisatory style featuring isolated fragments of running passages in alternation

\footnotetext{
${ }^{9}$ Shooshanik Apoian, Muzikalnaya Kultura Armianskoy SSR:Fortepiannaya Muzika Sovetskoy Armenii [Music Culture of Armenian S.S.R.: Keyboard Music of Soviet Armenia] (Moscow: Muzika, 1985), 322366.
} 
with more chordal textures. Dissonant sonorities dominate, with D and A functioning less as tonal centers than as pivotal axes. Interval classes 1 and 3 act as leitmotivs throughout the Six Pictures and are associated with traditional folk songs. The middle presto, toccata-like section is based on building blocks of interval classes 2 and 5 .

In Traditional, after four measures of introduction, the opening theme incorporates aspects of twelve-tone organization based on a twelve-tone row with the retrograde order in the left hand. Figure 2 shows the row table for this series.

\begin{tabular}{|c|c|c|c|c|c|c|c|c|c|c|c|c|c|}
\hline & $I_{11}$ & $I_{11}$ & $\mathrm{I}_{\mathrm{x}}$ & $\mathrm{I}_{7}$ & $\mathrm{I}_{3}$ & $\mathrm{I}_{2}$ & $I_{10}$ & $\mathrm{I}_{9}$ & $\mathrm{I}_{6}$ & $\mathrm{I}_{5}$ & $\mathrm{I}_{\downarrow}$ & $I_{1}$ & \\
\hline$P_{01}$ & 0 & $1 \mathrm{I}$ & 8 & 7 & 3 & 2 & I0 & 9 & 6 & 5 & 4 & I & $\mathrm{R}_{0}$ \\
\hline$P_{1}$ & I & 0 & 9 & 8 & 4 & 3 & 11 & 10 & 7 & 6 & 5 & 2 & $\mathrm{R}_{1}$ \\
\hline $\mathrm{P}_{4}$ & 4 & 3 & 0 & 11 & 7 & 6 & 2 & 1 & 10 & 9 & 8 & 5 & $\mathrm{R}_{4}$ \\
\hline$P_{5}$ & 5 & 4 & 1 & 0 & 8 & 7 & 3 & 2 & 11 & 10 & 9 & 6 & $\mathrm{R}_{5}$ \\
\hline$P_{y}$ & 9 & 8 & 5 & 4 & 0 & Il & 7 & 6 & 3 & 2 & I & 10 & $\mathrm{R}_{9}$ \\
\hline$P_{111}$ & 10 & 9 & 6 & 5 & 1 & 0 & 8 & 7 & 4 & 3 & 2 & $1 \mathrm{I}$ & $\mathrm{R}_{10}$ \\
\hline $\mathrm{P}_{2}$ & 2 & I & 10 & 9 & 5 & 4 & 0 & 11 & 8 & 7 & 6 & 3 & $\mathrm{R}_{2}$ \\
\hline$P_{3}$ & 3 & 2 & 11 & 10 & 6 & 5 & I & 0 & 9 & 8 & 7 & 4 & $\mathrm{R}_{3}$ \\
\hline$P_{0}$ & 6 & 5 & 2 & 1 & 9 & 8 & 4 & 3 & 0 & 11 & 10 & 7 & $R_{6}$ \\
\hline P- & 7 & 6 & 3 & 2 & 10 & 9 & 5 & 4 & 1 & 0 & II & 8 & $\mathrm{R}_{7}$ \\
\hline$P_{8}$ & 8 & 7 & 4 & 3 & 11 & 10 & 6 & 5 & 2 & I & 0 & 9 & $\mathrm{R}_{8}$ \\
\hline \multirow[t]{2}{*}{$P_{11}$} & I 1 & 10 & 7 & 6 & 2 & I & 9 & 8 & 5 & 4 & 3 & 0 & $\mathrm{R}_{11}$ \\
\hline & $\mathrm{RI}_{0}$ & $\mathrm{RI}_{11}$ & $\mathrm{RI}_{8}$ & $\mathrm{RI}$ - & $\mathrm{RI}_{3}$ & $\mathrm{RI}_{2}$ & $R I_{10}$ & $\mathrm{Rl}_{9}$ & $\mathrm{RI}_{6}$ & $\mathrm{RI}_{5}$ & $\mathrm{RI}_{4}$ & $\mathrm{RI}_{1}$ & \\
\hline
\end{tabular}

Figure 2. Babadjanyan: Traditional row table. 
It is easy to recognize the similarity of the main theme in this piece with that of the Armenian folk dance called Darchni. See the following Figure 3:

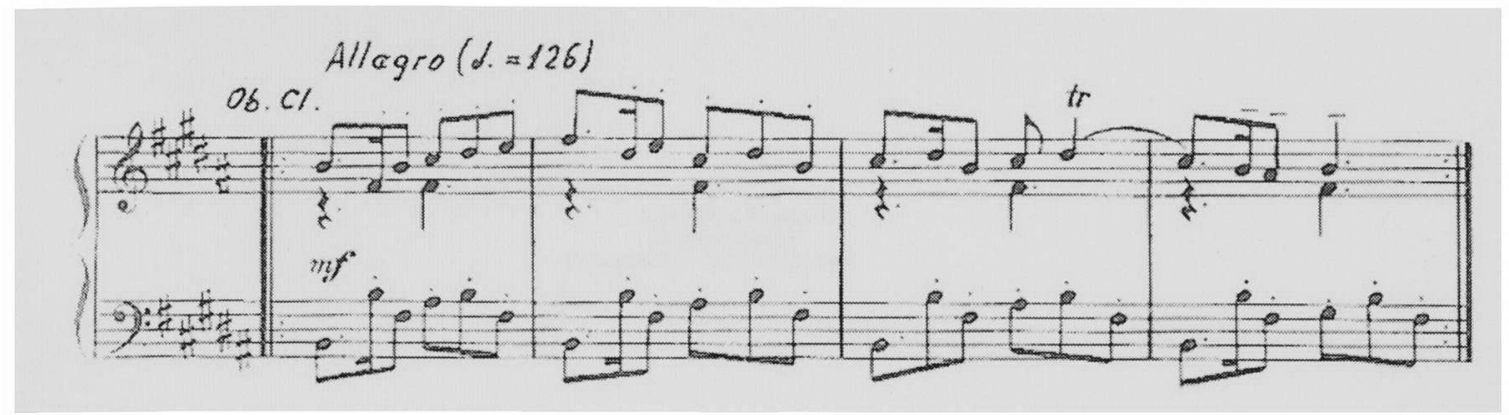

Figure 3. Armenian Folk Dance Darchni.

Among Babadjanyan's best piano works are such pieces as Prelude and Vagharshapat Dance, Elegy in memory of Aram Khachaturyan, Poliphonic Sonata, and Humoresque.

The Vagharshapat Dance, based on an original theme by Komitas, opens with a miniature melodic Prelude in B-flat minor reminiscent of Chopin's preludes and those of the young Scriabin. It is composed in four-measure segments; the melodic line travels from F-minor to C-minor in a "call and response" order, as shown in Figure 4. 


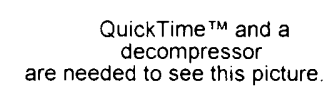

Figure 4. Babadjanyan: Prelude.

The end of the Prelude marks the beginning of the Vagharshapat Dance. Though it is not explicitly written that way, Babadjanyan himself performed the piece by holding the very last F-minor chord and then beginning the Vagharshapat Dance attaca with a drumlike, percussive fortissimo entrance in B-flat major. The time signature is $6 / 8$, which is commonly used in Armenian folklore as well as in most Eastern European dances. Babadjanyan bases his melody on a famous Armenian dance called "Rangi," which was used before by various composers such as Komitas and later N. Tigranian. Figures $5 \& 6$ illustrate versions of the same dance by Tigranian and Babadjanyan, respectively. 


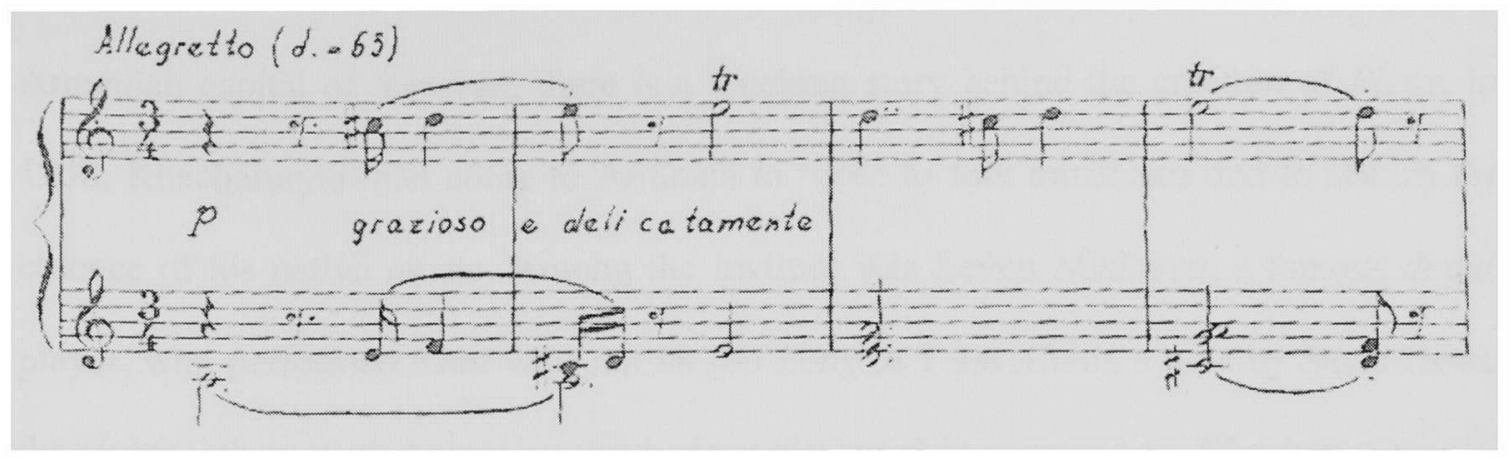

Figure 5. Tigranian: Rangi.

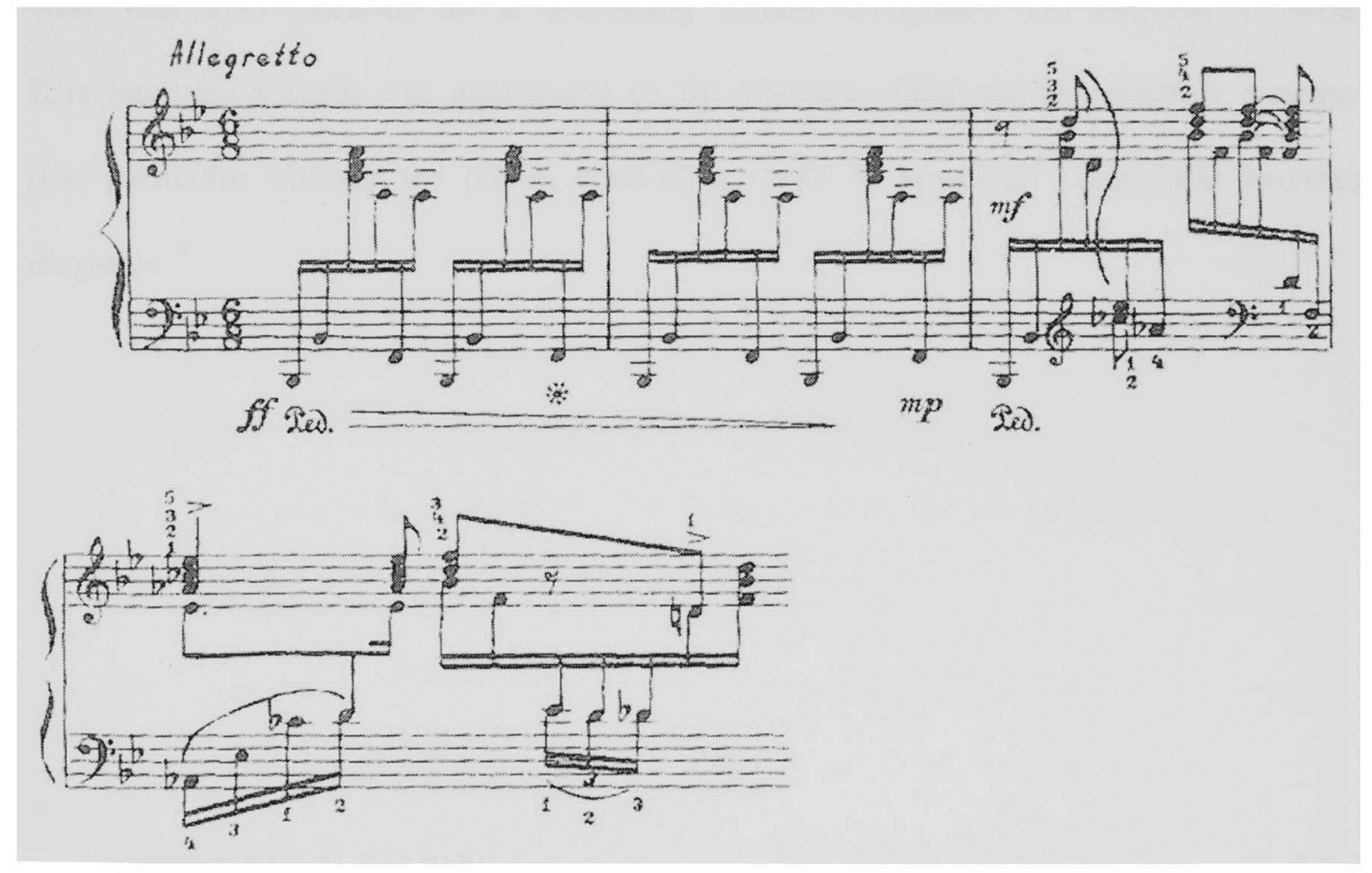

Figure 6. Babadjanyan: Vagharshapat Dance.

Babadjanyan composed Elegy in memory of Khachaturyan, who had been his mentor. As related by Gohar Harutunyan, the curator of the Khachaturyan Museum in the 
Armenian capital of Yerevan, there is a touching story behind the creation of Elegy. In 1938, Khachaturyan had come to Armenia to listen to folk musicians and to absorb the essence of his native music. Among the invitees was Levon Madoyan, a famous duduk player, who performed Kani voor jan im (So Long as I Am Alive), a tune by Sayat Nova, the eighteenth century Armenian troubadour discussed in chapter one. Khachaturyan was mesmerized and responded effusively to the beautiful melody of the song, calling it a superhuman creation. The incident left a mark on the memory of the young Babadjanyan, who was also present, as a promising young composer. He recalled it when Khachaturyan's death was announced on the Moscow radio and immediately arranged that particular melody for piano, creating a work of nostalgic beauty and haunting elegance. $^{10}$

${ }^{10}$ Sahan Arzruni, "Starring Armenians: The Music of Arno Babadjanyan," Keyboard Classics \& Piano Stylist (1994): 54 . 


\section{CHAPTER VI}

\section{EDUARD BAGDASARIAN}

Eduard Bagdasarian (1922-1985) was not a prolific composer, but some of his 24 Preludes for Piano, written in 1961, became popular among pianists and conservatory students.

Bagdasarian was born in 1922, was educated in Yerevan, Armenia, and later continued his studies in Moscow. His links to classical Armenian music are evident in his interest in folk melodies and modal harmony. Armenian national traditions and the music of Khachaturian and Rachmaninoff were the formative influences on the style of Bagdasarian's music, which combines inner intensity with the lyricism of Armenian folksong.

Among his compositions are a String Quartet (1949), Sonata for Clarinet and Piano (1950), Piano Quintet, Suite for Symphonic Orchestra (1962), Rhapsody for Violin and Symphony Orchestra (1958) and a few works written for theatre and movies. He had a penchant for chamber music and his 24 Preludes show him as a delicate lyricist and a master of small forms.

The Prelude in B minor is a character piece, akin to Mendelssohn's "Song Without Words", because it expresses a particular mood or atmosphere, in addition to the presence of a national element in its modal harmonies. It is written in ternary $\left(\mathrm{A}-\mathrm{B}-\mathrm{A}^{\prime}\right)$ form, in which the sections are distinctly set apart. It starts with a consistent arpeggiation accompaniment pattern with heightened attention given to the melody, which is doubled in the upper and lower voices. See Figure 7. 


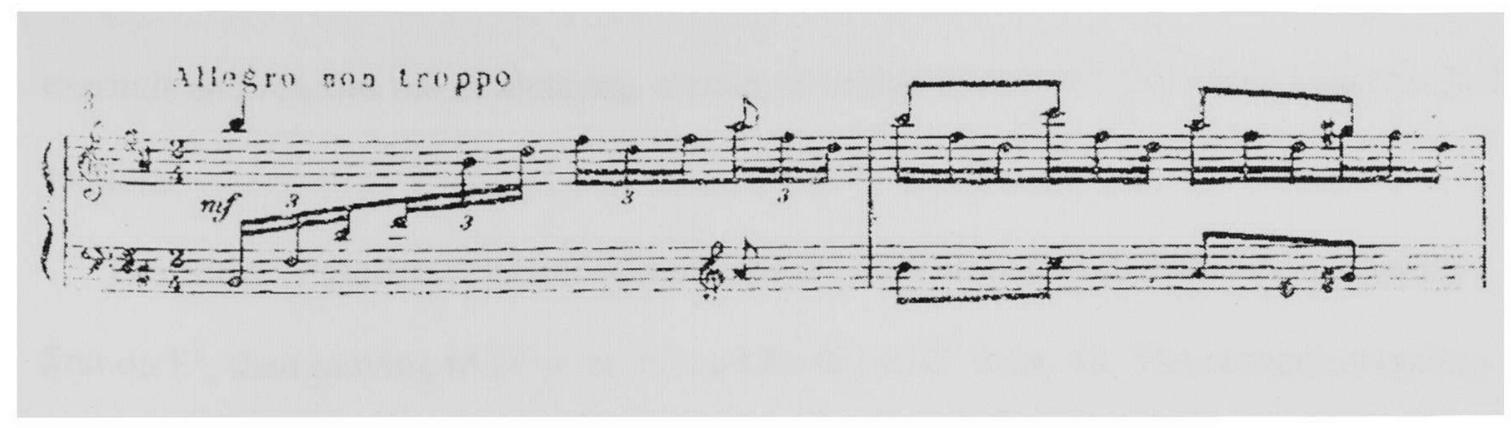

Figure 7. Bagdasarian: Prelude, opening theme.

\begin{tabular}{|l|l|l|l|l}
\hline Section: & A1 & A2 & A1 & A3 \\
\hline Measures: & $1-12$ & $13-20$ & $21-32$ & $33-46$ \\
\hline Main Key(s): & B minor & $\mathrm{C} / \mathrm{D}^{\#}\left(\mathrm{E}^{\mathrm{b}}\right)-\mathrm{E}^{\mathrm{b}}-\mathrm{C} / \mathrm{E}^{\mathrm{b}}$ & $\mathrm{B}$ minor & $\mathrm{C} / \mathrm{D}^{\sharp}\left(\mathrm{E}^{\mathrm{b}}\right)-\mathrm{G}^{\sharp}\left(\mathrm{A}^{\mathrm{b}}\right) / \mathrm{F}$ \\
\hline
\end{tabular}

Figure 8. Bagdasarian: Prelude, A section overview.

The melody is written in B Dorian minor over a pedal point until m.12. Most of Bagdasarian's Preludes have folk-like melodies; accordingly, they tend to be written in modes or given a modal "flavor," as are the melodies of many Soviet -era composers. The A2 section is articulated with a change of the pedal point to $\mathrm{C}$, arriving on lowered $2^{\text {nd }}$ on $\mathrm{C}$ natural. The melody emphasizes the Phrygian $2^{\text {nd }}$ degree.

In the $\mathrm{A} 2$ section he alternates harmonically between $\mathrm{C}$ major and $\mathrm{D}^{\sharp} / \mathrm{E}^{\mathrm{b}}$ major. Measure 34 is significant, because for the first time the composer is using a new key of $\mathrm{F}$ major.

A3 starts like A2, but later accelerates, starting with a faster harmonic rhythm via sequences, faster melodic movement rising in range and dynamics, and repetitiveness in mm. 45-46 as preparation for the climactic point in $\mathrm{m}$. 47. It then grows into a climax, 
expands and reaches the modulating section or bridge in $\mathrm{mm} .47-53$, which leads to the $\mathrm{B}$ section.

The entire B section is based on one melodic idea presented in mm. 54-61 starting first on $E^{b}$, then moving to $D^{b}$ in $m .62$ and finally to $C^{b}$ in $m$. 68 . The composer arrives to $A^{\prime}$ at the Tempo I in m. 97. The form of the entire piece can be symbolized by Figure 9.
A
B
$\mathbf{A}^{\prime}$
a1 a2 a1 a3 bridge b1 a1 a2 bridge-Coda.

Figure 9. Bagdasarian: Prelude, an overview of the form. 


\section{CHAPTER VII}

\section{ALEXANDER ARUTIUNIAN: DANCE OF SASOON}

The music of the Soviet Armenian composer, Alexander Arutiunian, who held the title of "People's Artist of the USSR," is often compared to the canvases of his compatriot, Martiros Saryan. In the work of both these artists - composer and painter - we sense the same gamut of color, the same bright, rich strokes, the same bold touch of a master, the same immersion in national folklore, the same wealth of classical traditions, the same inexhaustible youthful spirit.

Alexander Arutiunian was born on September 23, 1920, in the city of Yerevan, Armenia. He began to study music in 1927, in the Children's Group of the Yerevan Conservatory. Here, the composer A. Spendiarov, the dean of Soviet Armenian musicians, took note of him and predicted a promising future for the young musician. In 1941, the young composer completed his studies at Yerevan Conservatory, receiving his diploma in both composition and piano. Since then he has received numerous awards in Armenia, the USA and elsewhere.

Arutiunian has tried his hand at a wide range of genres. His flashy Trumpet Concerto (1950) is one of the finest compositions for wind instruments and is performed worldwide. The use of folk-inflected material with strong rhythmic features truly serves the ideas of the author and is the basis of his compositions. His music is by turns lyric and dramatic. It is dynamic, full of intelligence and emotion. 
His compositions continue the tradition of Khachaturyan in their combination of a highly colorful and decorative style.

The ashug tradition, based on freely varied development, has been important to Arutiunian's work in general. His lyrical idiom is rooted in a specific national melodic character, while the Romantic side of his sensibility finds expression in an emotional radicalism and a predominantly lyrical impulse, producing music that is at once expressive, sentimental, nostalgic and ironic. ${ }^{11}$

Dance of Sasoon is one of three pieces from his Musical Pictures for Piano, written in 1961. It captivates the audience with its exhilarating, impetuous strong rhythmic bass ostinato, which starts from the very first measures and continues throughout the whole piece, creating a high degree of emotional intensity.

"Svetlana Sarkisyan, "Arutiunian, Aleksandr Grigori," Oxford Music Online, http://www.oxfordmusiconline.com.ezproxy.fiu.edu/subscriber/article/grove/music/12490 (accessed November 27, 2008). 


\section{CIIAPTER VIII}

\section{A. ARUTIUNIAN - A. BABADJANYAN: ARMENIAN RHAPSODY FOR TWO PIANOS}

The Armenian Rhapsody for Two Pianos was composed in 1950. It is a joint collaboration of two composers, Arno Babadjanyan (see chapter 5) and his friend Alexander Arutiunian (see chapter 7).

In 1950, Babadjanyan returned to his homeland of Armenia, where he became a professor of piano at the Yerevan Komitas Conservatory. During this time of his life, he composed frequently and gave numerous performances. Always aware of his national roots, Babadjanyan's compositions became a major success and are still widely performed in the Armenian Diasporas and all over the world by nonArmenian performers.

The Armenian Rhapsody for Two Pianos comprises two pieces or movements combined into one large musical act. The melodic structure is based on the repetition of a rhythmic pattern, which is highly typical for parerger (dance-songs). The lyrical Andante movement, in 6/8 meter, is in D major. The second piano starts with a typical rhythmic Armenian dance accompaniment, while the first piano plays a soft dance melody based on Mixolydian D mode. See Figure 10. 


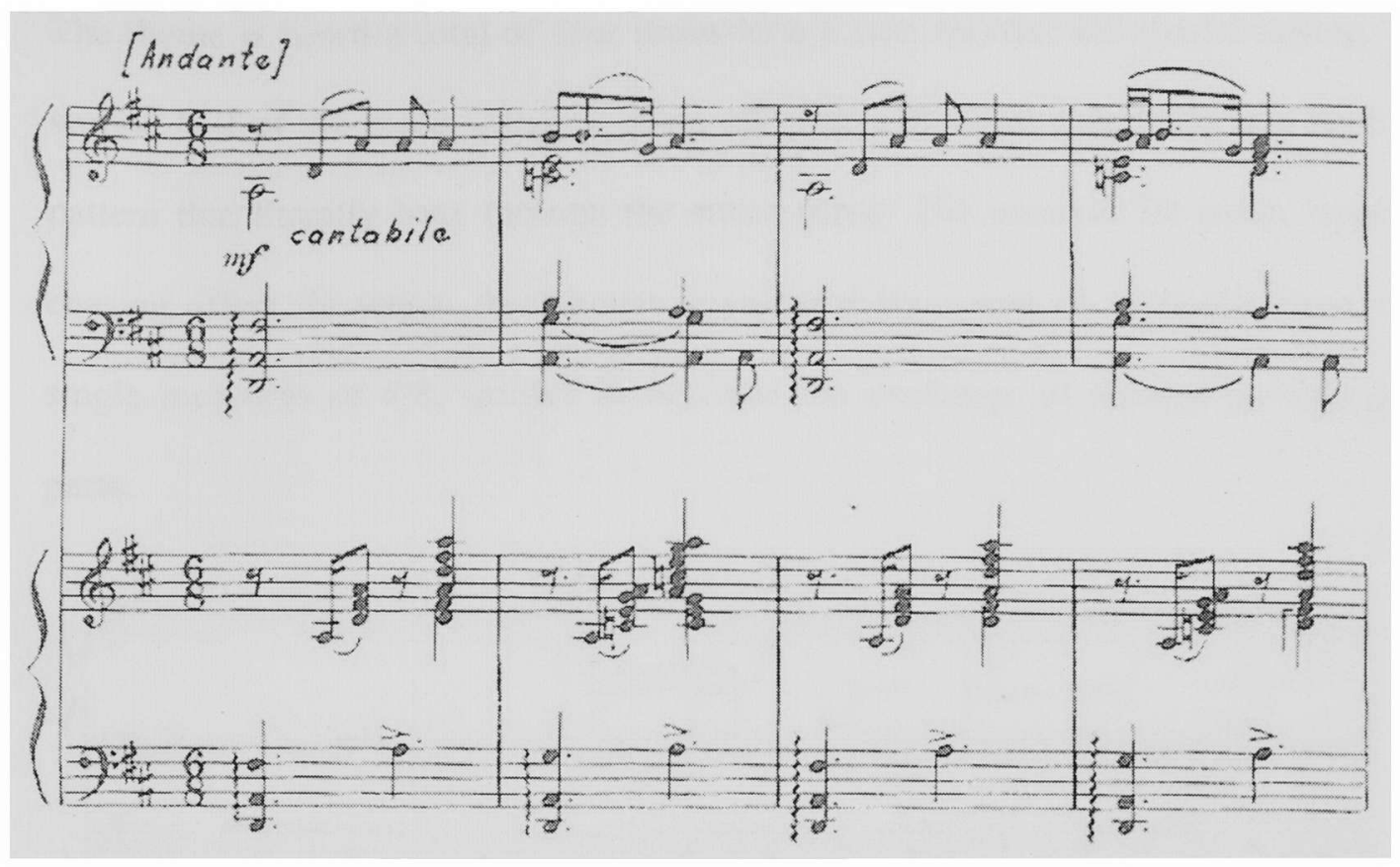

Figure 10. Arutiunian-Babadjanyan: Armenian Rhapsody for Two Pianos.

In the opening first 14 measures the melody is based on a pedal point. With modal changes that lead into a minor, the dance-like movement continues with a call and response from both pianos, keeping a steady dance accompaniment. The dynamics and the intensity of the piece grow, as the melody returns in the first piano in double octaves. A few subito piano markings impersonate the movements of Armenian dancers, who frequently raise their arms high, then with a sudden movement bring them down below their waists, while mimicking thoughts with expressive finger movement. The theme in the Andante is a call and response in itself, consisting of twelve measures, with three groups of two plus two measures. When the theme concludes in the first piano, the second piano repeats it in a slightly varied setting. 
The theme is heard a total of four times with a rich chordal and modal setting. The second half of the piece, Allegro, starts off with a dynamic crescendo and rhythmic pattern that literally lasts through the entire piece. The unusual $5 / 8$ meter creates a chasing affect, in which the listener is captured by a web of rhythmic ideas, with single measures of $6 / 8$, thrown in between the exchange of themes in both piano parts.

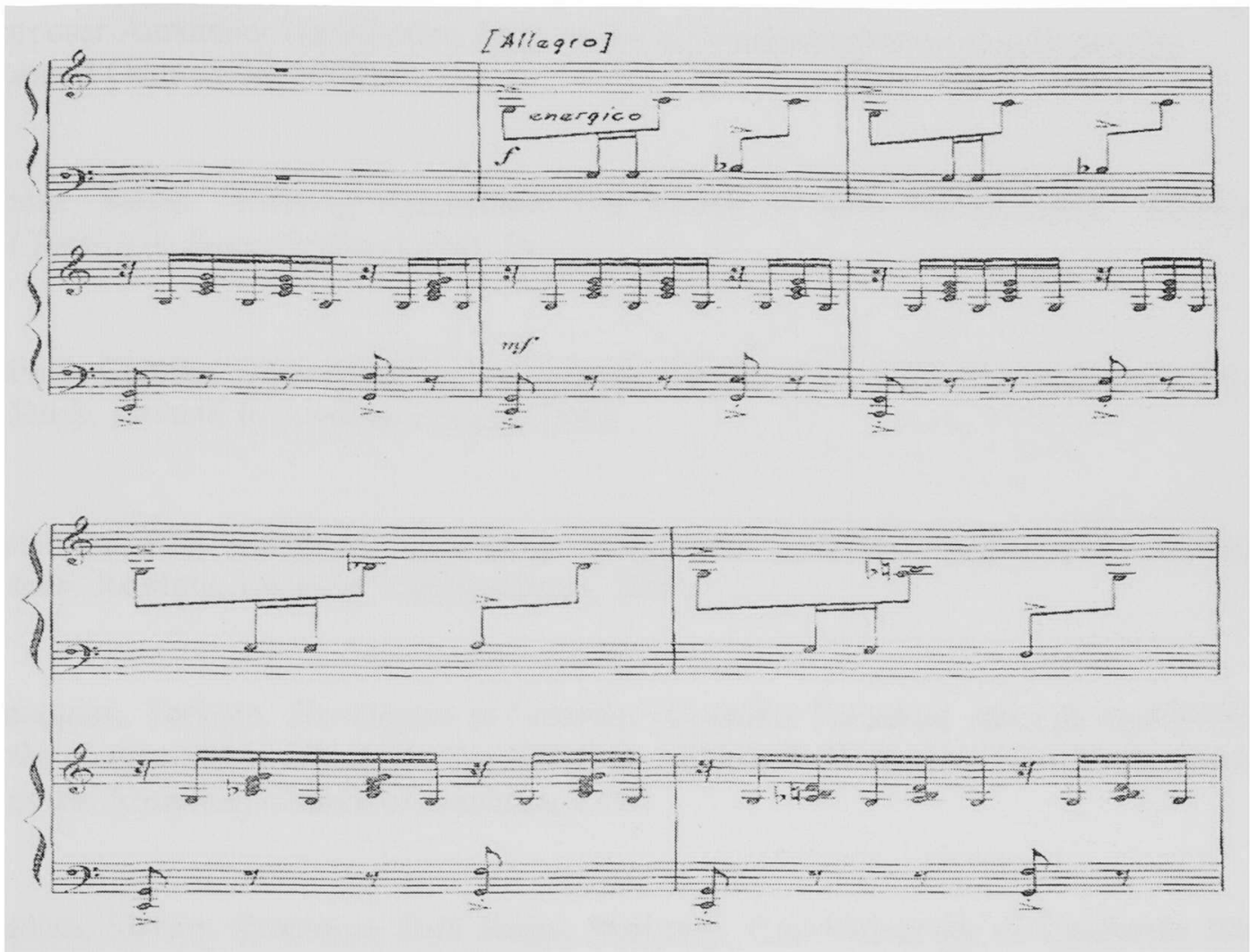

Figure 11. Arutiunian-Babadjanyan: beginning of the Allegro section.

The piece ends with a bombastic accelerando and a dramatic crescendo with effective ascending and descending glissandos in both pianos, reaching lowest and highest octave C's. It is a great finale for any recital. 


\section{BIBLIOGRAPHY}

Apoian, Shooshanik. Robert Andriasian. Yerevan: Sovetakan Grox, 1984.

Apoian, Shooshanik. Muzikalnaya Kultura Armianskoy SSR:Fortepiannaya Muzika Sovetskoy Armenii [Music Culture of Armenian S.S.R.: Keyboard Music of Soviet Armenia]. Moscow: Muzika, 1985.

Arutiunian, Alexander. "Alexander Arutiunian." The Official Website of the Armenian Composer Alexander Harutiunian. http://www.alexanderarutiunian.com/home.htm (accessed October 26, 2008).

Arzruni, Sahan. "Starring Armenians: The Music of Arno Babadjanyan." Keyboard Classics \& Piano Stylist (1994): 54.

Dowsett, Charles. Sayat Nova. An $18^{\text {th }}$-century Troubadour. A Biographical and Literary Study. Lovanii In Aedibus Peeters, 1997.

Kuyumjian, Rita Soulahian. Archeology of Madness: Komitas, Portrait of an Armenian Icon. Reading, England: Taderon Press, 2001.

Manoogian, Torkom. The Genius of Gomidas (Gomidas Vartabed, His Life and Work on the Centennial of His Birth. Translated by Shahan R. Berberian. New York: Diocese of the Armenian Church of America, 1969.

Poladian, Sirvart. Armenian Folk Songs. Berkeley, CA: University of California Press, 1942.

Sarkisyan, Svetlana. "Khachaturian, Aram (Il'ich)." Oxford Music Online. http://www.oxfordmusiconline.com.ezproxy.fiu.edu/subscriber/article/grove/music/1

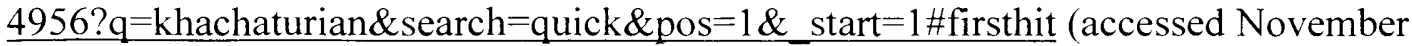
$28,2008)$. 
Sarkisyan, Svetlana. "Arutiunian, Aleksandr Grigori." Oxford Music Online. http://www.oxfordmusiconline.com.ezproxy.fiu.edu/subscriber/article/grove/music/1 2490 (accessed November 27, 2008).

Shneyerson, G.M. Aram Khachaturyan: Stranitsi Ghizni I Tvorchestva [Pages from His Life and Works]. Moscow: Sovetski Kompozitor, 1982.

Virtual Museum of Komitas. "Biography of Komitas." Virtual Museum of Komitas. http://www.komitas.am/ eng/brief.htm (accessed August 30, 2008). 